\title{
Retail Investor's Perceived Usefulness of Corporate Social Media: A Technology Acceptance Model Perspective
}

\author{
MUHAMMAD NAVEED \\ Ph.D. Scholar, Department of Management Studies, Bahria University Islamabad. \\ Email: Qm.naveed@outlook.com \\ NOSHABA BATOOL \\ Assistant Professor, Air University School of management, Air University. \\ Email: Noshaba.batool@mail.au.edu.pk \\ BUSHRA KARIM MIRZA \\ Lecturer, Air University School of management, Air University. \\ Email: Bushra@mail.au.edu.pk
}

\begin{abstract}
This study's basic premise is to examine the retail investor perspective regarding the decision usefulness of the corporate website. Corporate social media play a vital role in determining stakeholder behavioral intentions. This study's concern is to evaluate how a corporate website, as a corporate social media tool affects retail investor behavioral intentions. The technology acceptance model and signaling theory conjunction provide the foundation for developing the proposed theoretical framework. Structural Equation Modeling (SEM) has been carried out to examine the strength of the measurement model statistically. The study's findings suggest that the corporate website as a social media toll positively influences the retail investor behavioral intention. The perceived ease of use positively impacts the actual usage intention of the corporate website by investors to effectively make their investment decisions. Similarly, the perceived usefulness of corporate websites significantly impacts the investor's behavioral intentions to engage in corporate social media. The proposed model is novel to insight the retail investor investment decision in the context of Pakistan. The study has implications for retail investors, listed companies on the stock exchange and regulators to understand how corporate websites remain robust for informed asset allocation decisions.
\end{abstract}

Keywords: Corporate Social Media, Corporate Website, Retail Investor, Pakistan Stock Exchange.

\section{Introduction}

Information technology has gained the utmost significance in various aspects of our lives. In 2019, there were more than 4 billion internet users worldwide, an $83 \%$ increase since the year 2000 (Internet World Statistics, 2019). As of 2019, more than 55\% of the world's population has internet access. The rapid expansion of internet technology and its adoption has transformed the way corporations interact and attract customers. Similarly, internet technology reformed social media users' expectations and patterns (Ageeva, Melewar, Foroudi, \& Dennis, 2019). In this new high-tech marketplace, corporations still strive to build relationships with stakeholders (Ageeva, Melewar, Foroudi, Dennis, \& Jin, 2018). According to Akman and Mishra (2017), when corporations struggle to build long-lasting relationships with stakeholders, the corporate website should be pivotal. Therefore, a corporate website's formation and maintenance is a crucial corporate strategy for a corporation's success in the high-tech marketplace. 
Conversely, corporations have various design concerns when formulating their corporate social media presence (Alalwan, Dwivedi, Rana, \& Williams, 2016). Consequently, corporations should learn to formulate corporate websites that effectively meet the stakeholder's expectations (Bilgihan, Barreda, Okumus, \& Nusair, 2016). The effective quality of the corporate website remains significant because it serves as the main interface with the stakeholders. Therefore, by using their corporate website, corporations gain a competitive edge, improved stakeholders' relationships, and enable financial reporting and decision usefulness (Cade, 2018). In line with these trends, corporate websites are widely being used as a tool for disseminating financial information. Financial information provides the basis to make a sound investment decision. The basic intent of the proposed study is to determine how corporate websites influence retail investor investment behavior.

Past studies advocate that retail investors perceive decision usefulness by using financial information. Financial information supports investors in recalling data and making economic decisions more effectively (Foroudi, Jin, Gupta, Melewar, \& Foroudi, 2016).

In line with these trends, corporate social media has gained widespread attention (Ageeva et al., 2019). However, despite the significance, there are limited empirical evidence that proclaims the true meaning of a favorable corporate website (Go \& You, 2016). Moreover, there is a gap regarding the favorable corporate website and its antecedents, dimensions, and potential effects (Hair Jr, Hult, Ringle, \& Sarstedt, 2016). Particularly, accounting research has overlooked the retail investor's decision usefulness by using the financial information disclosed on the corporate website. Past studies explicitly proclaim that multimedia should affect decision-makers; however, studies provide limited evidence about the role of perceived usefulness, ease of use, and usage of corporate websites.

The signaling theory perspective has been used to analyze the potential impact of corporate website favorability on retail investor financial information usage. The signaling theory posits that an organization sends various signals through different channels to attract and inform stakeholders. The study's significance prevails to financial managers and academics since there is limited empirical evidence on corporate website favorability (Jung, Naughton, Tahoun, \& Wang, 2017). Therefore, managers need to prudently scrutinize the constructs of their corporate website to influence retail investor behavior and sustain their corporate reputation (Kühn, Stiglbauer, \& Fifka, 2018). Second, this study aims to disclose how corporate website favorability affects the retail investor's effective responses and intention to use information disclosed on the corporate website. Third, the study's contextual setting is provided by retail investor trading at Pakistan Stock Exchange (PSX), for whom there are limited empirical evidence available. Therefore, this research provides how retail investors perceive decision usefulness about the financial information disclosed on the corporate website. Conclusively, the study's findings will be prudent to managers who remain engage in the creation and maintaining corporate websites to disclose financial information.

\section{Conceptual Framework \& Hypothesis Development}

The utility of information in decision making is prevalent and academic literature has placed increased attention on the corporate disclosure of financial information. Past studies confirm the utility of financial information in decision making. There are limited evidence regarding the decision usefulness of financial information in the context of retail investors. Information disclosure reflects a business's transparency by disclosing its financial and strategic information (Lee, Chung, \& Kang, 2008). The main thrust of the financial information disclosure is to provide relevant information that will assist stakeholders to forecast future cash flows of a firm. In line with this objective, there is an abundant amount of research focusing on how various stakeholders (analysts, institutional investors) respond to the decision usefulness of financial disclosures (Ali, Yousaf \& Naveed, 2020; Manetti \& Bellucci, 2016).

Quality and reliability of financial information disclosure is positively attributed with general market liquidity (Nel \& Brummer, 2016), institutional ownership (Pant \& Pant, 2018) and negatively documented 
with agency cost (Sarstedt, Ringle, \& Hair, 2017) and cost of equity financing (Schumacker, 2017). The foregoing literature reflected empirical studies that mainly relate to the market as opposed to retail investors. Moreover, the context of retail investor behavior postures a divergent framework to insight the role of financial and non-financial information in determining their trading activity at stock market. Likewise, most of the past studies relevant to financial and nonfinancial information have been conducted by considering institutional investor perspective rather than retail investor(Stohl, Etter, Banghart, \& Woo, 2017).

Contrary to the opinion that retail investor only relies on intermediaries (brokers, media), evidence suggests that retail investor scrutinize the financial disclosure to make a sound investment decision. Financial information remains a major source to know about the operational and performance efficiency of a business entity (Ali, shah and Chughtai, 2019). The stakeholder, including both retail investor and institutional investor, perform technical and fundamental analysis before making an investment decision and extending this notion of how financial information disclosure via conventional and non-conventional ways matter and perceived by the user? Many studies about disclosure have mainly examined the conventional ways (not on the corporate website) of disclosing financial information (Turmin, Hamid, \& Ghazali, 2016). As the attractiveness of the internet grew, corporate websites were largely conceived as a novel way of tool to interact with stakeholders(Raza, Naveed \& Ali, 2017). The pioneer past studies about web-based financial reporting (Hansen, Saridakis, \& Benson, 2018; Jung et al., 2017; Pant \& Pant, 2018; Schumacker, 2017) disclosed that by the late 2000s, most of the corporations disclosed financial information on their corporate websites. However, there was a great divergence in the amount and type of information disclosed. This extends the question of relevance and peripheral cues associated with information disclosure. In line with this trend, corporations can now provide access to financial information via their corporate websites. The web-based visual cues tend to persuade and change the user's opinions (Venkatesh \& Davis, 2000). The web-based financial disclosure is pervasive and has gained widespread recognition. Accordingly, the Financial Accounting Standards Board (FASB) statistics outline that $95 \%$ of top 100 Fortune companies disclosed $94 \%$ of their financial information on their corporate websites (Yahia, Al-Neama, \& Kerbache, 2018).

\section{Multimedia and Decision Support}

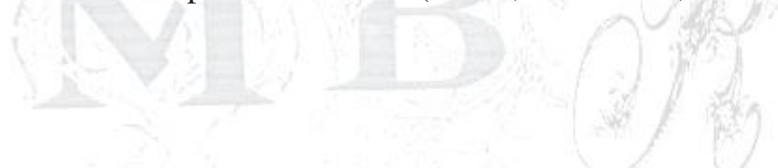

Corporate website enriches with multimedia information exhibit its benefit because its cues are positively asserted and enabled by web technology. Multimedia significantly improves the user interface and usability of financial information uploaded on the web. Retail investors rely heavily on multimedia information due to a surge in information technology.

Multimedia information rooted in decision-support improves investors' capabilities to make sound investment decisions (Zhao, Chen, \& Wang, 2016). A decision support system provides a user-interface with massive amounts of data and consolidates information to resolve problems and make thorough decisions. Multimedia applications are widely used for education, training, media engineering and communications. Multimedia information is a composite of graphics, text, numeric, and charts; hence remains easy to comprehend and useful for decision making. Multimedia enhances the text presentations and improves the presentation's quality by attaining the audience's attention. Moreover, web-based multimedia reduce information costs and enable retail investors to access relevant information more conveniently (Zhao et al., 2016).

Multimedia equips the investors to learn through instructional messages, which are communications using more than text, such as narration, animation, and pictures intended to promote user understandability. Multimedia applications are widely recognized in online and unified learning for its benefits. Learning through graphics and animations remain better than words and text alone. Graphics represent static illustrations such as maps, charts, drawings and animation (Cade, 2018). Such enrich learning in online environment allows the investor to infer more logical and informed decision-making. 
Literature based on cognitive psychology posits three main assumptions underlying the cognitive theory of multimedia learning, namely dual channel, limited capacity and active processing. Dual-channel assumption holds the conception that human information processing is processed separately for visual and auditory represented information. While limited capacity assumptions reflect the notion that visual and auditory channels have limited processing capacity and active processing represents extensive cognitive processing while using visual and auditory channels for learning (Foroudi et al., 2016).

The underlying rationale for multimedia learning is that investors effectively scrutinize financial information when they process information according to the cognitive theory of multimedia learning principles. Studies expounded in previous literature mainly focused on the benefits of multimedia and design principles for learning, its adoption has rarely been explored in the context of retail investor decision (Naveed, Saif \& Sindhu, 2017).

Substantively few studies have discussed the adoption of multimedia in learning. Akman and Mishra (2017), have studied the determinants of learner's behavior intention to engage in multimedia learning by using the technology acceptance model. However, past studies have examined by incorporating exogenous factors on behavioral intention and overlooking the adoption mechanism in actual behavior (Naveed et al., 2020). The underlying study aims to study the actual adoption behavior in adopting multimedia technology for investor learning (Lee et al., 2008).

\section{Technology Acceptance Model (TAM)}

Technology adoption and success remain significant for information systems researchers and have been extensively studied by using various theoretical perspectives and models. The most notable model includes the IS success model, task technology fit model. However, the most widely used model employed by past studies is the technology acceptance model that emphasizes technology adoption by individuals based on perceived ease of use and usefulness. The reason action theory offers the underlying mechanism about the technology acceptance model. (Stohl et al., 2017; Venkatesh \& Davis, 2000) and have been extensively employed in the various contextual setting to determine user adoption of technology. TAM has been employed by various utility-based technologies, particularly word processors computers, the internet, and retail technology (Kühn et al., 2018).

In line with previous studies, the current study employed a technology acceptance model (TAM) to examine the multimedia information decision usefulness in the retail investor context. The technology acceptance model was pioneered by Venkatesh and Davis (2000), which posits that two perceptions mainly attribute an individual attitude toward information technology: usefulness, the tendency to believe that using a particular system would enrich the task performance and ease of use denotes the extent to believe that using a particular system would be convenient i.e. "free of effort". The perceived intention to use a system leans to adopt the technology, which in turn reflects the individual actual usage behavior. Hence, the technology acceptance model is based on user-perceived usefulness and ease of use of information technology. The technology acceptance model has been widely employed and empirically tested in past studies of technology acceptance (Turmin et al., 2016).

The outcome variable of the technology acceptance model is actual usage. Many empirical studies have examined additional relationships. The study of Cade (2018) posits that perceived enjoyment and computer playfulness are the main antecedents of perceived ease of use. Pant and Pant (2018) also advocate that ease of use and perceived usefulness positively leaned individual intention towards online shopping. Past studies have also incorporated various external variables into the technology acceptance model (Stohl et al., 2017). The most quoted and frequently studied variables are training, system quality, computer anxiety, and selfefficacy (Jung et al., 2017). In this study, external variables are incorporated as the corporate website dimension central to access financial information for the purpose of the retail investor's investment decisions. 


\section{Theoretical Model and Hypothesis Development}

Based on substantive literature, the proposed model is based on Davis (1989). The study employed TAM by using nine constructs. The first five constructs as depicted in figure 1, affecting two main variables such as perceived usefulness and perceived ease of use, are cohesively relevant to multimedia richness a central part of the financial website (Venkatesh \& Davis, 2000).

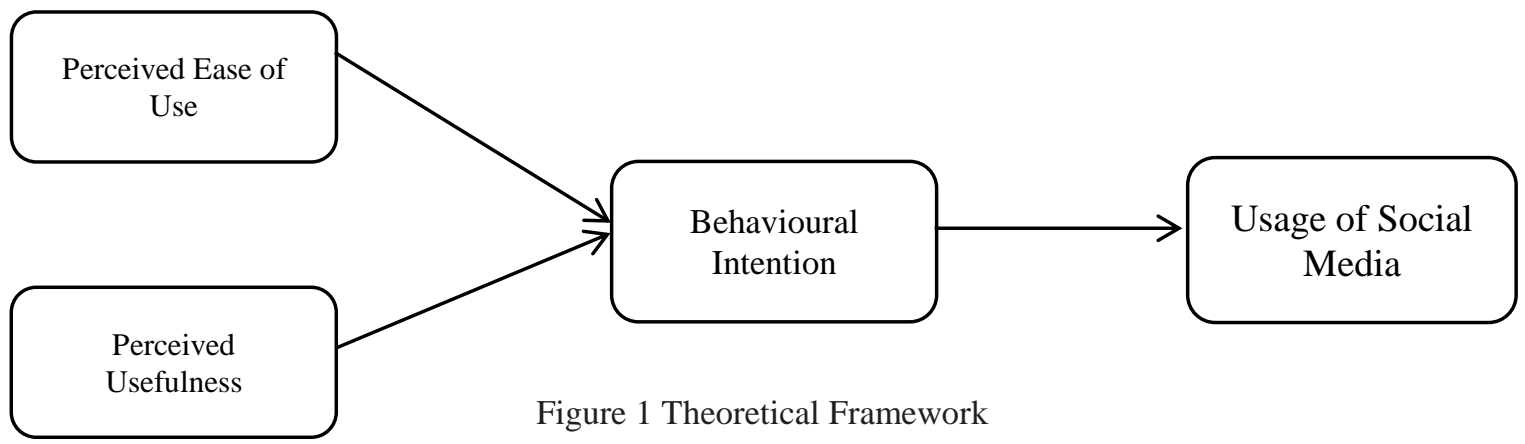

The first three hypotheses by following original TAM are proposed based on the assumption that retail investors have an access to a single corporate website containing financial information. In line with theory and the relationship between behavioral intention and actual behavior is conceived as one of the basic TAM relationships and supported by past studies (Ageeva et al., 2019). Thus, the first hypothesis of the study is postulated as:

$\mathbf{H}_{\mathbf{1}}$ : Retail investor's behavioral intention positively impacts corporate website usage to access financial information

Perceived ease of use stands as the key behavioral construct in the technology acceptance model (Venkatesh \& Davis, 2000). Past studies proclaim that ease of use plays a pivotal role in the actual usage behavior of information-oriented technologies (Akman \& Mishra, 2017). Given the significance of the financial information, the ease of use is hypothesized to be more robust in predicting retail investors' intention to access financial information via the corporate website. Therefore, the second hypothesis of the study is proposed as:

$\mathbf{H}_{2}$ : Retail investor's perceived ease of use positively impacts their behavioral intention to use a corporate website to access financial information.

$\mathrm{H}_{2-\mathrm{a}}$ : Retail investor's perceived usefulness positively impacts their intention to use a corporate website to access financial information.

The first construct consistency is measured by three items adopted from (Alalwan et al., 2016; Lee et al., 2008). Consistency is a golden rule in design and reflects logical coherence and uniformity. The consistency of a web provides a quality experience to users by providing coherence in both design and content of a webpage. The building blocks of a website are term as web elements. Web elements are central to web framework and should be kept consistent. The usability of a website is heavily depended on logic, which is accomplished with consistency. The next dimension of a website, technical convenience, represents the tendency of ease user perceive about the webpage. The technical convenience construct is measured by three items adopted from (Foroudi et al., 2016). According to Venkatesh and Davis (2000) a number of external variables leaned to perceived ease of use however, in this study, it is presumed that consistency and technical convenience positively influence the retail investor's behavioral intention about 
ease of use. Extending this notion, the following hypothesis are projected about the possible impact of consistency and technical convenience.

The next oblivious feature of a financial website is investment information. This feature allows retail investors to make an informed decision. Investment information is measured by three items projected by (Yahia et al., 2018). However, the utility of investment information is entrenched with information quality. The quality of the content of the information system is pivotal to rely on information and being considered a relevant fit for use. Retail investor seeks information which remains align with their need to make a sound investment decision. Therefore, the quality of information serves as an integral feature of a corporate website. To operationalize the quality of information five items measure is adopted form (Sarstedt et al., 2017). Decision quality, another feature of a corporate website, demonstrates the effectiveness and efficiency of decision analysis. Decision quality matters a lot when decision-making involves allocating resources with the expectation of profit (Naveed et al., 2020). The stock market is subject to great risk(Yousaf \& Ali, 2020); therefore, the decision's quality is exceptional while examining retail investor behavior. The decision quality construct is measured by using three items outlined by (Bilgihan et al., 2016). In line with past studies, it is postulated that investment information, information quality, and decision quality positively impact user-perceived behavioral usefulness while using the corporate website. Hence, the following hypothesis is projected:

\section{Research Methodology \\ Data Collection and Sample}

Based on substantive literature and research model, primary data through questionnaire was collected. The study use a questionnaire having nine constructs all adopted from past studies. A brief detail of the constructs and their corresponding items are being summarized in table 1. The population of the study comprised Pakistani retail investors selected randomly. However, they must have involved in one transaction in 2018 at the PSX (Pakistan Stock Exchange). The sample includes only retail investors (nonprofessional investors) who directly or indirectly engage in a relationship with any PSX company (Iqbal \& Brooks, 2007). A professional investor (stockbrokers and portfolio analysts) with personal portfolios are being discarded because the group does fall in the scope of this study. To achieve the maximum geographical distribution for the survey, investor from all around Pakistan were included.

Four hundred and fifty questionnaires were distributed out of which three hundred and eighty seven questionnaires were returned. However, thirty-three questionnaires were discarded due to error of omission incurred by respondents. The observations are dropping from subjects due to partial or absolute missing items relevant in the model (Alalwan et al., 2016). Hence, after dropping the incomplete questionnaire, the final valid questionnaires was three hundred and fifty-four. Studies expounded in past literature proclaim that for structural equation models generally range between 200 to 400 (Hair, Ringle, \& Sarstedt, 2013).

The demographic characteristics of the sample include gender, age, education, experience, and income. The majority of the respondents were men (93\%) and comparatively young $(73 \%)$ less than fifty years old). Female participation was low due to the socioeconomic and conservative culture of Pakistan. $84 \%$ of the respondents hold at least a bachelor's degree while some of them also hold a master's degree. Similarly the median value of experience and level of income were 7 and PKR 750,000 per annum respectively. The survey responses were based on five points Likert scale ranging from strongly agrees to strongly disagree. The response rate of the survey was $78.66 \%$.

\section{Statistical Tools and Technique}

The study's proposed model was empirically tested by using multivariate statistical analysis through structural equation modeling (SEM). Statistical analysis was carried out by using LISREL 9.30. Before 
proceeding the structural equation modeling model was first checked and then fixed based on Chi-square statistics before estimates on each path are examined ((Hair et al., 2013). Path analysis was conducted to determine the magnetite and significance of the causal relationship between model construct. The outcome of path analysis leads to determine the best fit model.

\section{Confirmatory Factor Analysis}

Confirmatory factor analysis (CFA) was carried out to obtain the construct validity. All of the nine constructs was tested as a distinct model with latent variables to determine their fitness. The values for all the statistics fall within acceptable thresholds. Regarding all cases, comparative fit index (CFI) 0.91, goodness of fit index $(\mathrm{GFI})>0.90$, adjusted goodness of fit index $(\mathrm{AGFI})>0.80$, root mean square residual (RMSA) $<0.10$ and normed fit index $(\mathrm{NFI})>0.90$. The CFA indices state a good model fit measure (Thompson, 2004). The value remained within an acceptable level and reported in table 1.

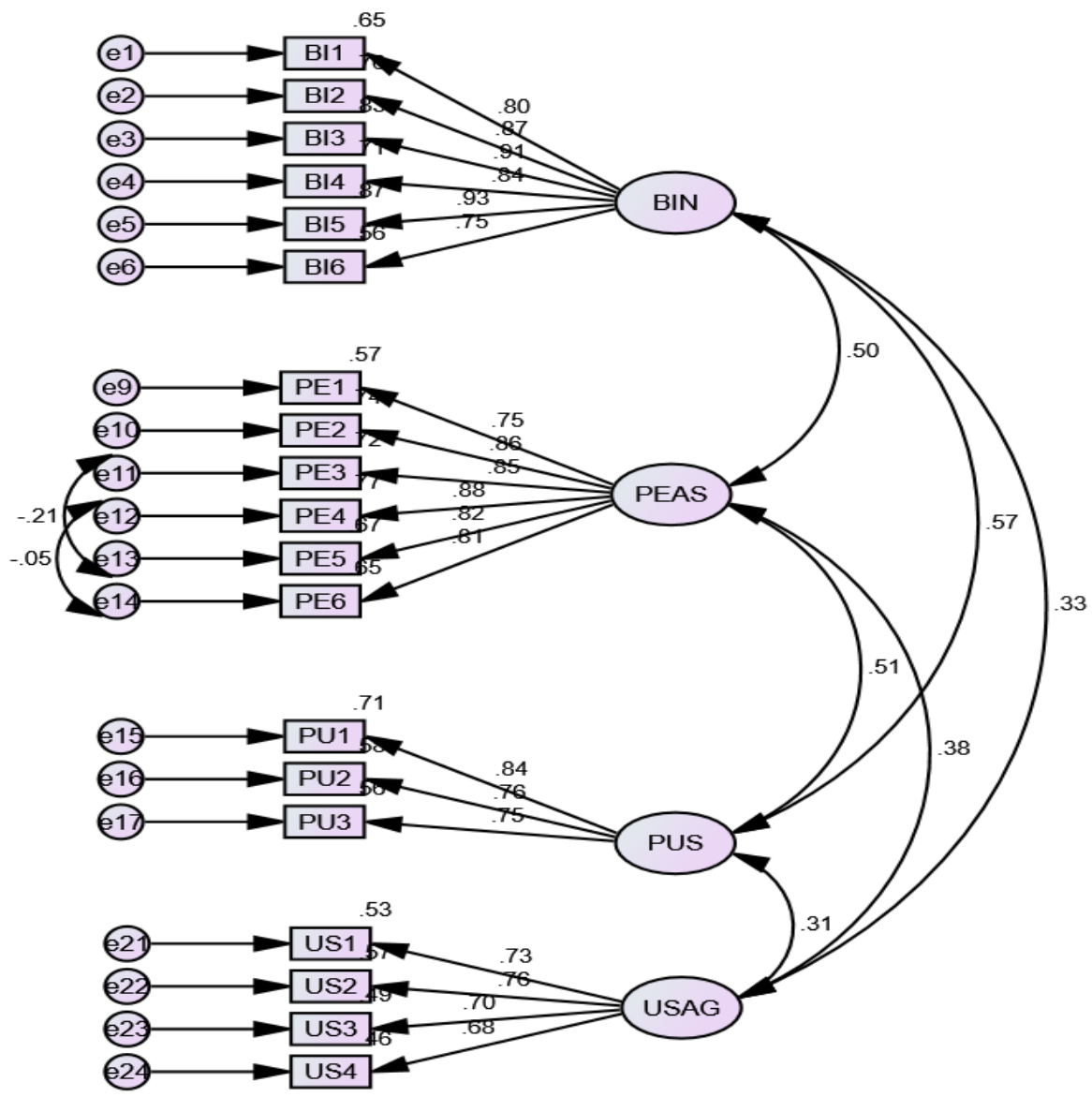

Figure 2: CFA 
Table $1:$ Factor Loading of Standardized Estimates

\begin{tabular}{|c|c|c|c|c|c|}
\hline Variable & Item & Loading & $\mathrm{CR}$ & AVE & Cronbach Alpha \\
\hline \multirow{4}{*}{ Usage } & US1 & 0.712 & 0.812 & 0.760 & 0.871 \\
\hline & US2 & 0.734 & & & \\
\hline & US3 & 0.854 & & & \\
\hline & US4 & 0.832 & & & \\
\hline \multirow{3}{*}{$\begin{array}{l}\text { Perceived } \\
\text { Usefulness }\end{array}$} & PU1 & 0.765 & 0.749 & 0.667 & 0.868 \\
\hline & PU 2 & 0.777 & & & \\
\hline & PU 3 & 0.798 & & & \\
\hline \multirow{6}{*}{$\begin{array}{l}\text { Perceived Ease of } \\
\text { Use }\end{array}$} & PE1 & 0.815 & 0.810 & 0.659 & 0.836 \\
\hline & PE2 & 0.754 & & & \\
\hline & PE3 & 0.787 & & & \\
\hline & PE4 & 0.743 & & & \\
\hline & PE5 & 0.721 & & & \\
\hline & PE6 & 0.742 & & & \\
\hline \multirow{6}{*}{$\begin{array}{l}\text { Behavioral } \\
\text { Intention }\end{array}$} & BI1 & 0.843 & 0.918 & 0.573 & 0.885 \\
\hline & BI 2 & 0.736 & & & \\
\hline & BI 3 & 0.725 & & & \\
\hline & BI 4 & 0.772 & & & \\
\hline & BI 5 & 0.719 & & & \\
\hline & BI 6 & 0.664 & & & \\
\hline
\end{tabular}

\section{Descriptive Statistics and Normality}

A descriptive statistics and correlation matrix has been used to determine the data properties. The descriptive statistics table outline the mean and median values of the primary data collected through the survey. An online survey was collected to collect the responses of the target sample size. The sample size remains 324, and the values of standard deviation are aligned with the mean. Besides descriptive statistics, the correlation matrix reflects that all the explanatory variables are correlated with the dependent variable, and the explanatory variable has no such correlation, reflecting no multicollinearity issue.

\section{Descriptive Statistics \& Correlation Matrix}

Table 2: Descriptive and Correlation

\begin{tabular}{|lcccccc|}
\hline & Mean & SD & 1 & 2 & 3 & 4 \\
\hline $\begin{array}{l}\text { Perceived ease } \\
\text { of use }\end{array}$ & 4.131 & 0.765 & 1.000 & & & \\
$\begin{array}{l}\text { Perceived } \\
\text { usefulness }\end{array}$ & 4.714 & 0.743 & .437 & 1.000 & & \\
Intention to use & 4.192 & 0.721 & $.707^{* *}$ & $.784^{* * *}$ & 1.000 & \\
Usage & 4.321 & 0.743 & $.715^{* * *}$ & $.761^{* *}$ & $.674^{* * *}$ & 1.000 \\
\hline
\end{tabular}

**Correlation is significant at the 0.01 level

\section{Measurement Model \& Hypothesis Testing}

The covariance-based SEM has been employed to test the proposed model. The structural equation modeling result reflects that both financial and nonfinancial information predict the retail investor stock market investment. Analysis of SEM states that the entire hypotheses proposed based on literature are accepted. Table 3 summarizes the result of SEM through coefficients and corresponding t values. Statistical values demonstrate that perceived ease of use and perceived usefulness positively affect retail investor 
intention to use and actual usage of such information. The first hypothesis, i.e., the impact of behavioral intention on corporate social media usage, is positively significant (t-value, 3.619). The result infers that $1 \%$ increase in predictor results in a $20 \%$ change in the outcome variable. Likewise, perceived ease of use significantly determines ( $\mathrm{t}$-value, 3.321) behavioral intention of retail investors to use corporate social media (corporate website. Finally, the third hypothesis also remains significant (t-value, 2.417) to determine behavioral intention. The results are accorded with (Ageeva et al., 2019; Akman \& Mishra, 2017; Bilgihan et al., 2016; Hansen et al., 2018).

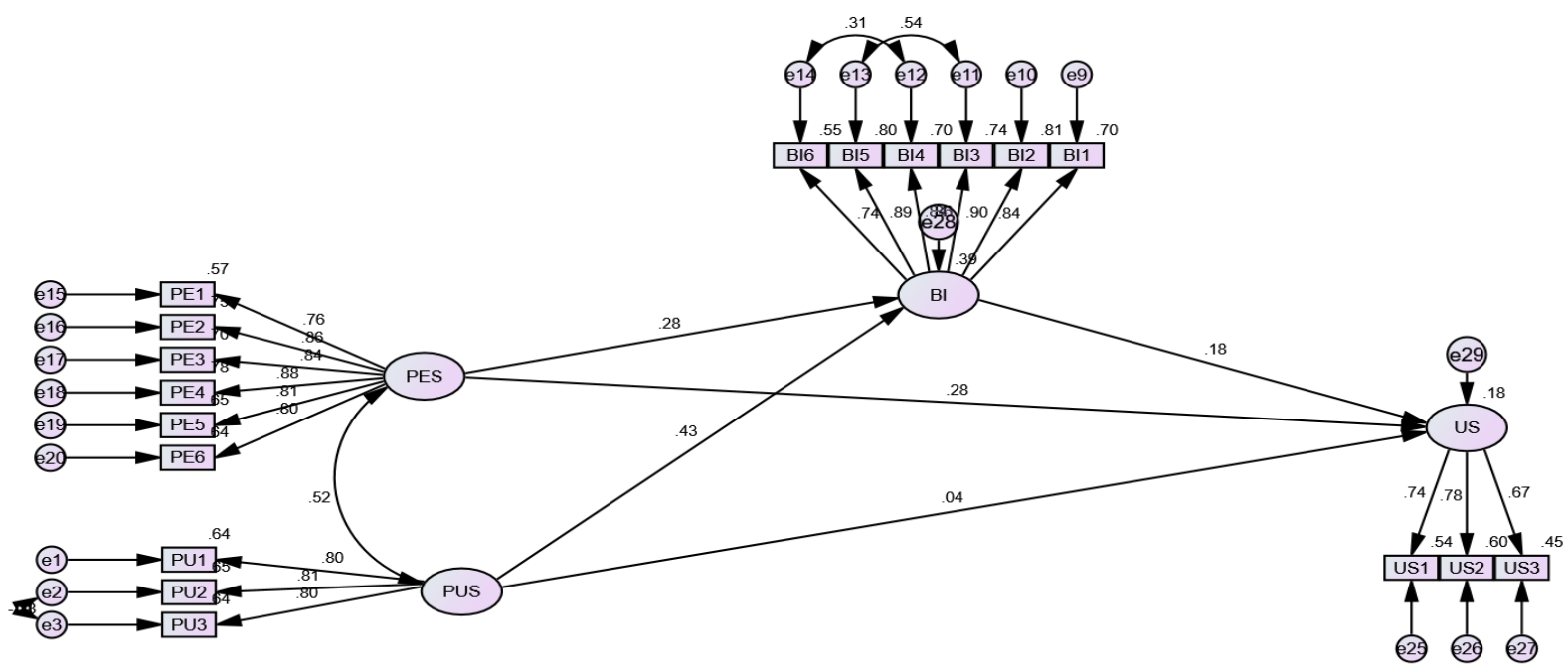

Figure 3 Measurement Model

Table 3. Hypotheses Test.

\begin{tabular}{|llclc|}
\hline Hypothesis & From & To & Coefficient & Results \\
\hline 1 & BI & US & $0.20^{* *}$ & 3.619 Accepted \\
$2-1$ & PES & BI & $0.15^{*}$ & 3.321 Accepted \\
$2-2$ & PUS & BI & $0.34^{* *}$ & 2.417 Accepted \\
\hline
\end{tabular}

\section{Discussion \& Conclusion}

The stock market is subject to uncertainty and retail investors remain exposed to a higher level of risk due to their lower level of risk tolerance. Therefore, to reduce uncertainty and make rational investment decisions, they mostly rely on information disclosure. Therefore, the corporate website plays a vital role in offering the enriching information disclosure source for investors to make sound investment decisions. The retail investor besides financial statements also uses the corporate website to access the relevant information about its future earnings. Therefore, the corporate website should contain such content that can influence the retail investor's attitude toward buying a particular company's stocks.

Corporate website plays a vital role in disseminating information and affecting the stakeholder behavioral intention to use this information to make sound investment decisions. In the age of the social media revolution, a corporate website presence is essential to engage with customer, investors, and other concerned stakeholders. This study provides evidence of how retail investors perceive corporate websites 
and how they use it to make sound investment decisions. Therefore, organizations should pay attention to their corporate website content while formulating their corporate social media strategy.

This finding is congruence with past studies expound in literature which assert that perceived ease of corporate website positively influences the stakeholder behavioral intention, which in turn affect their perceived usage of the corporate website (Ageeva et al., 2019; Ageeva et al., 2018; Akman \& Mishra, 2017; Alalwan et al., 2016; Cade, 2018). Similarly, the study of Pant and Pant (2018) also advocates that the perceived usefulness of social media affect behavioral intention and determine stakeholder behavior to make an online purchase decision (Naveed et al., 2020).

The findings of this study propose that management should integrate social media while formulating its strategic policies. Particularly, an active and vibrant approach toward corporate website development and managing a favorable corporate image. Therefore, this study provides empirical evidence about the decision usefulness of the corporate website in the context of individual investor investment decisions.

Conclusively, the study's findings advocate that social media play a vital role in determining the investor's behavioral intention and their actual usage of information being disclosed on the corporate website. The result confirms the decision usefulness of the corporate website and reflects the role of social media in information disclosure. The findings may be utility-oriented for companies designing their corporate website and striving toward a strong social media presence. Besides building a favorable image, the corporate website is customer-centric and targeting target audiences. The current investigation climaxes the significance of social media particularly corporate websites as a route for achieving corporate vision and mission. The study findings reflect that the corporate website and social media remain vital in determining corporate identity management.

The study is subject to certain limitations. Convenience sampling, a non-statistical sampling technique, is being used to collect the data from targeted respondents. According to Sarstedt et al. (2017), "convenience samples are very common and indeed are more prominent than are samples based on probability sampling" (p. 198). Though most of the social science research used a convenience sample for validating a theory, a statistical sampling technique should be used in future studies to mitigate the potential bias in terms of convergent and discriminate validity. Therefore, the findings' generalizability will be made with caution, and sample size limitations should be considered.

\section{References}

Ageeva, E., Melewar, T., Foroudi, P., \& Dennis, C. (2019). Cues adopted by consumers in examining corporate website favorability: An empirical study of financial institutions in the UK and Russia. Journal of Business Research, 98, 15-32.

Ageeva, E., Melewar, T., Foroudi, P., Dennis, C., \& Jin, Z. (2018). Examining the influence of corporate website favorability on corporate image and corporate reputation: Findings from fsQCA. Journal of Business Research, 89, 287-304.

Akman, I., \& Mishra, A. (2017). Factors influencing consumer intention in social commerce adoption. Information Technology \& People, 30(2), 356-370.

Alalwan, A. A., Dwivedi, Y. K., Rana, N. P., \& Williams, M. D. (2016). Consumer adoption of mobile banking in Jordan: examining the role of usefulness, ease of use, perceived risk and self-efficacy. Journal of Enterprise Information Management, 29(1), 118-139.

Ali, S., Yousaf, I., \& Naveed, M. (2020). Role of credit rating in determining capital structure: Evidence from non-financial sector of Pakistan. Studies of Applied Economics, 38(3).

Ali, S., Shah, S. Z. A., \& Chughtai, S. (2019). The Role of Bank Competition in influencing Bank Liquidity Creation: Evidence from China. Journal of Business \& Economics, 11(1), 21-34.

Bilgihan, A., Barreda, A., Okumus, F., \& Nusair, K. (2016). Consumer perception of knowledge-sharing in travel-related online social networks. Tourism Management, 52, 287-296. 
Cade, N. L. (2018). Corporate social media: How two-way disclosure channels influence investors. Accounting, Organizations and Society, 68, 63-79.

Foroudi, P., Jin, Z., Gupta, S., Melewar, T., \& Foroudi, M. M. (2016). Influence of innovation capability and customer experience on reputation and loyalty. Journal of Business Research, 69(11), 4882-4889.

Go, E., \& You, K. H. (2016). But not all social media are the same: Analyzing organizations' social media usage patterns. Telematics and Informatics, 33(1), 176-186.

Hair, J. F., Ringle, C. M., \& Sarstedt, M. (2013). Partial least squares structural equation modeling: Rigorous applications, better results and higher acceptance. Long range planning, 46(1-2), 1-12.

Hair Jr, J. F., Hult, G. T. M., Ringle, C., \& Sarstedt, M. (2016). A primer on partial least squares structural equation modeling (PLS-SEM): Sage publications.

Hansen, J. M., Saridakis, G., \& Benson, V. (2018). Risk, trust, and the interaction of perceived ease of use and behavioral control in predicting consumers' use of social media for transactions. Computers in Human Behavior, 80, 197-206.

Iqbal, J., \& Brooks, R. (2007). Alternative beta risk estimators and asset pricing tests in emerging markets: The case of Pakistan. Journal of Multinational Financial Management, 17(1), 75-93.

Jung, M. J., Naughton, J. P., Tahoun, A., \& Wang, C. (2017). Do firms strategically disseminate? Evidence from corporate use of social media. The Accounting Review, 93(4), 225-252.

Kühn, A.-L., Stiglbauer, M., \& Fifka, M. S. (2018). Contents and determinants of corporate social responsibility website reporting in Sub-Saharan Africa: A seven-country study. Business \& Society, 57(3), 437-480.

Lee, K. C., Chung, N., \& Kang, I. (2008). Understanding individual investor's behavior with financial information disclosed on the web sites. Behaviour \& Information Technology, 27(3), 219-227.

Manetti, G., \& Bellucci, M. (2016). The use of social media for engaging stakeholders in sustainability reporting. Accounting, Auditing \& Accountability Journal, 29(6), 985-1011.

Naveed, M., Saif, O. B., \& Sindhu, M. I. (2017). Impact of Bank Competition on Bank Liquidity Creation: Empirical Evidence from GCC and ASEAN Region.

Nel, G., \& Brummer, L. (2016). The development of a measurement instrument to measure the quality of internet investor relations. South African Journal of Business Management, 47(4), 15-25.

Naveed, M., Ali, S., Iqbal, K., \& Sohail, M. K. (2020). Role of financial and non-financial information in determining individual investor investment decision: a signaling perspective. South Asian Journal of Business Studies 9(2), 261-278. https://doi.org/10.1108/SAJBS-09-2019-0168

NAVEED, M., SINDHU, M. I., \& ALI, S. (2020). Role of Financial and Non-Financial Information in Shaping Trading Behavior: A Retail Investor's Perspective. Studies of Applied Economics, 38(3).

Pant, G., \& Pant, S. (2018). Visibility of corporate websites: The Role of information prosociality. Decision Support Systems, 106, 119-129.

Raza, M. A., Naveed, M., \& Ali, S. (2017). Determinants of internet banking adoption by banks in Pakistan. Management and Organizational Studies, 4(4), 12.

Sarstedt, M., Ringle, C. M., \& Hair, J. F. (2017). Partial least squares structural equation modeling. Handbook of market research, 1-40.

Schumacker, R. E. (2017). Interaction and nonlinear effects in structural equation modeling: Routledge.

Stohl, C., Etter, M., Banghart, S., \& Woo, D. (2017). Social media policies: Implications for contemporary notions of corporate social responsibility. Journal of Business Ethics, 142(3), 413-436.

Thompson, B. (2004). Exploratory and confirmatory factor analysis: Understanding concepts and applications: American Psychological Association.

Turmin, S. Z., Hamid, F. A., \& Ghazali, N. A. M. (2016). Corporate Internet Reporting Within Malaysian Economic Sectors. International Journal of Economics \& Management, 10(2).

Venkatesh, V., \& Davis, F. D. (2000). A theoretical extension of the technology acceptance model: Four longitudinal field studies. Management science, 46(2), 186-204.

Yahia, I. B., Al-Neama, N., \& Kerbache, L. (2018). Investigating the drivers for social commerce in social media platforms: Importance of trust, social support and the platform perceived usage. Journal of Retailing and Consumer Services, 41, 11-19. 
Yousaf, I., \& Ali, S. (2020). The COVID-19 outbreak and high frequency information transmission between major cryptocurrencies: evidence from the VAR-DCC-GARCH approach. Borsa Istanbul Review. https://doi.org/10.1016/j.bir.2020.10.003

Zhao, Q., Chen, C.-D., \& Wang, J.-L. (2016). The effects of psychological ownership and TAM on social media loyalty: An integrated model. Telematics and Informatics, 33(4), 959-972. 